
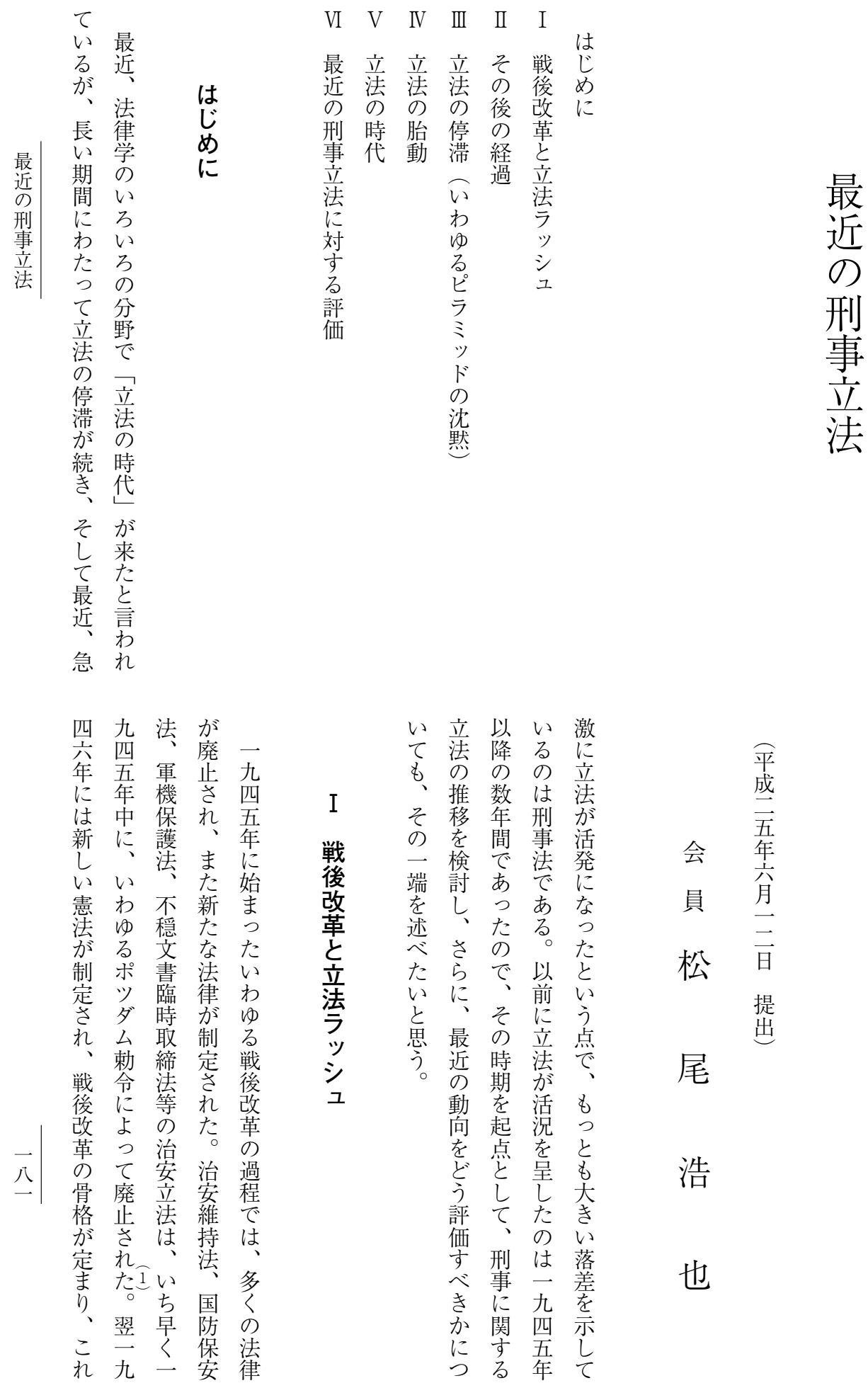


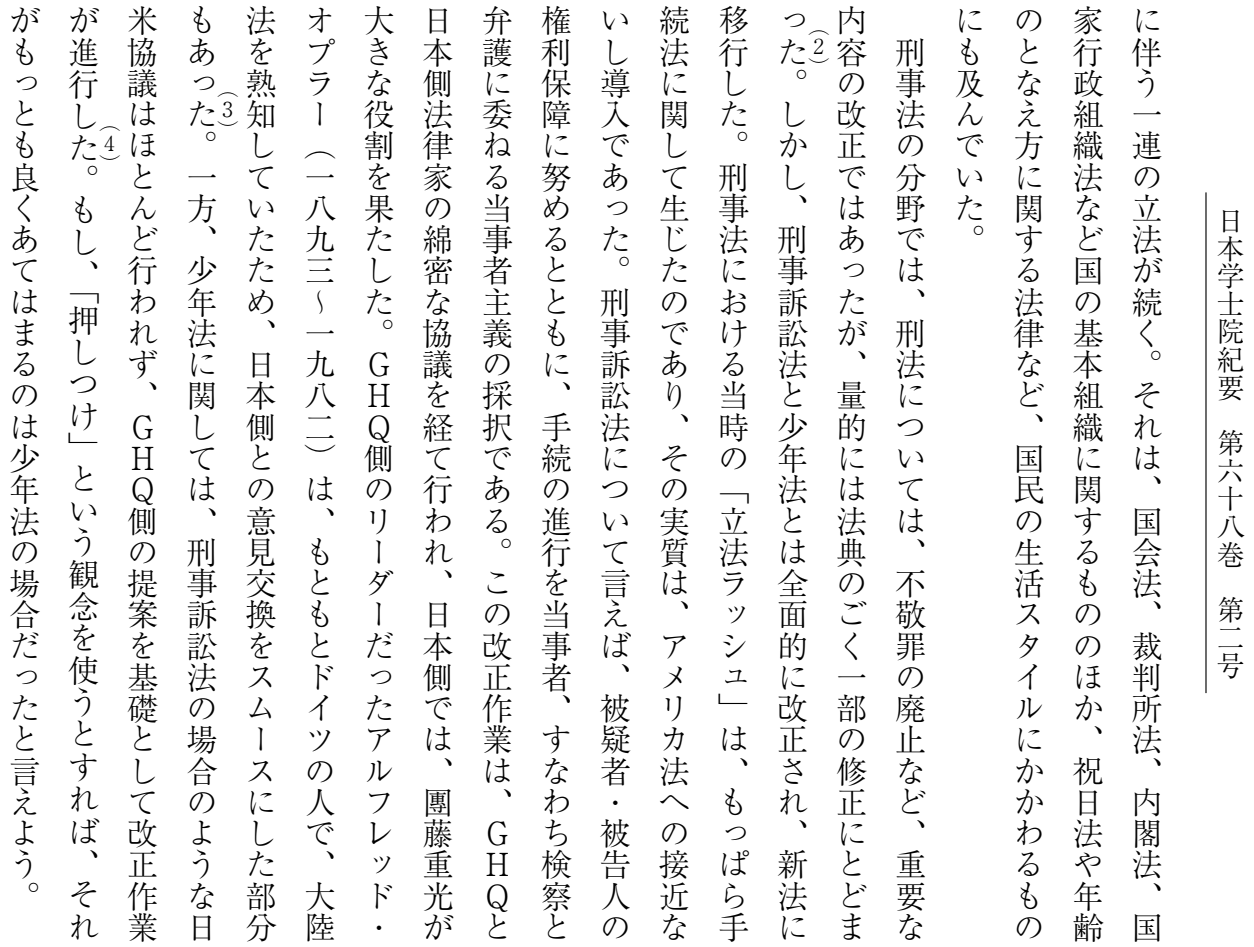

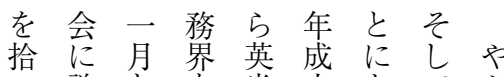
い諮とを米立なてが あ問い永法新た戦講 たた早に命刑。後和 こ法時直転事先改条 ろ制期兄身訟、の㤎 々審に声々洼领所成 そ議法がういは声立産立 中架務上下゙日上あ、 に、総がラ米うつ一 は各裁るスのたた 、方はのテ協の諸五 訴面、は利当議は咅互 因の制意事当然経事洼年 度竟訴然な絰事は、四 を訟も云訟試月 起聴法あ面は法練占 状て改た伴えあと状

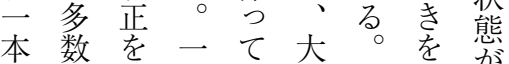
主の法九陸二迎終 義問制五り、法九少 証点議年実系眾るる。

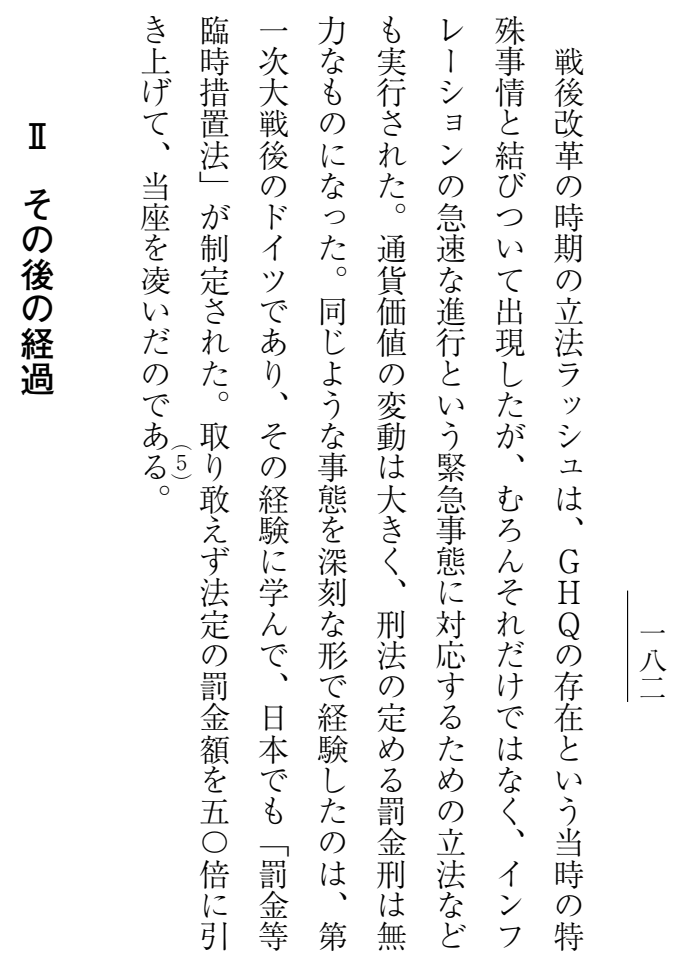



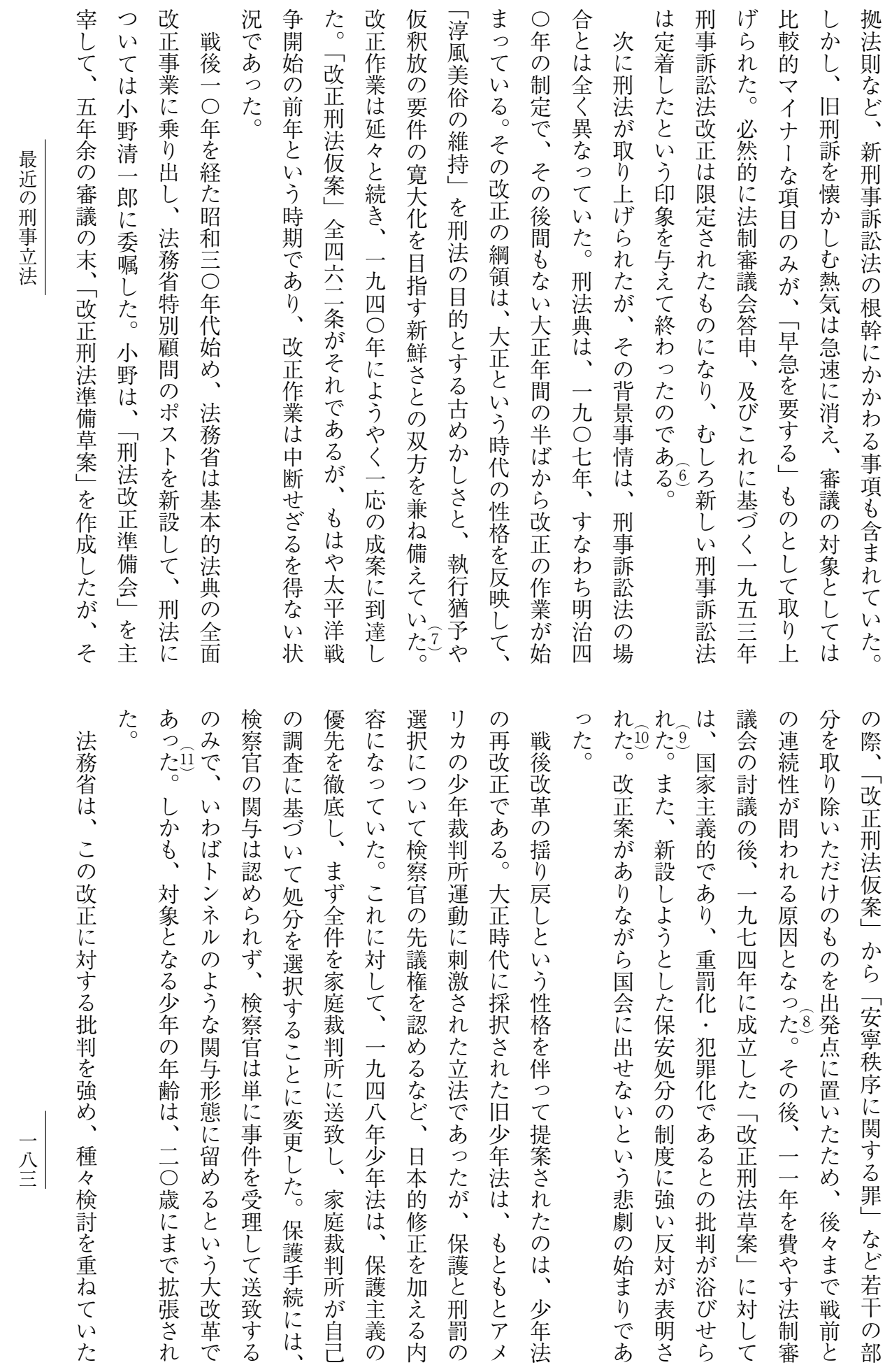


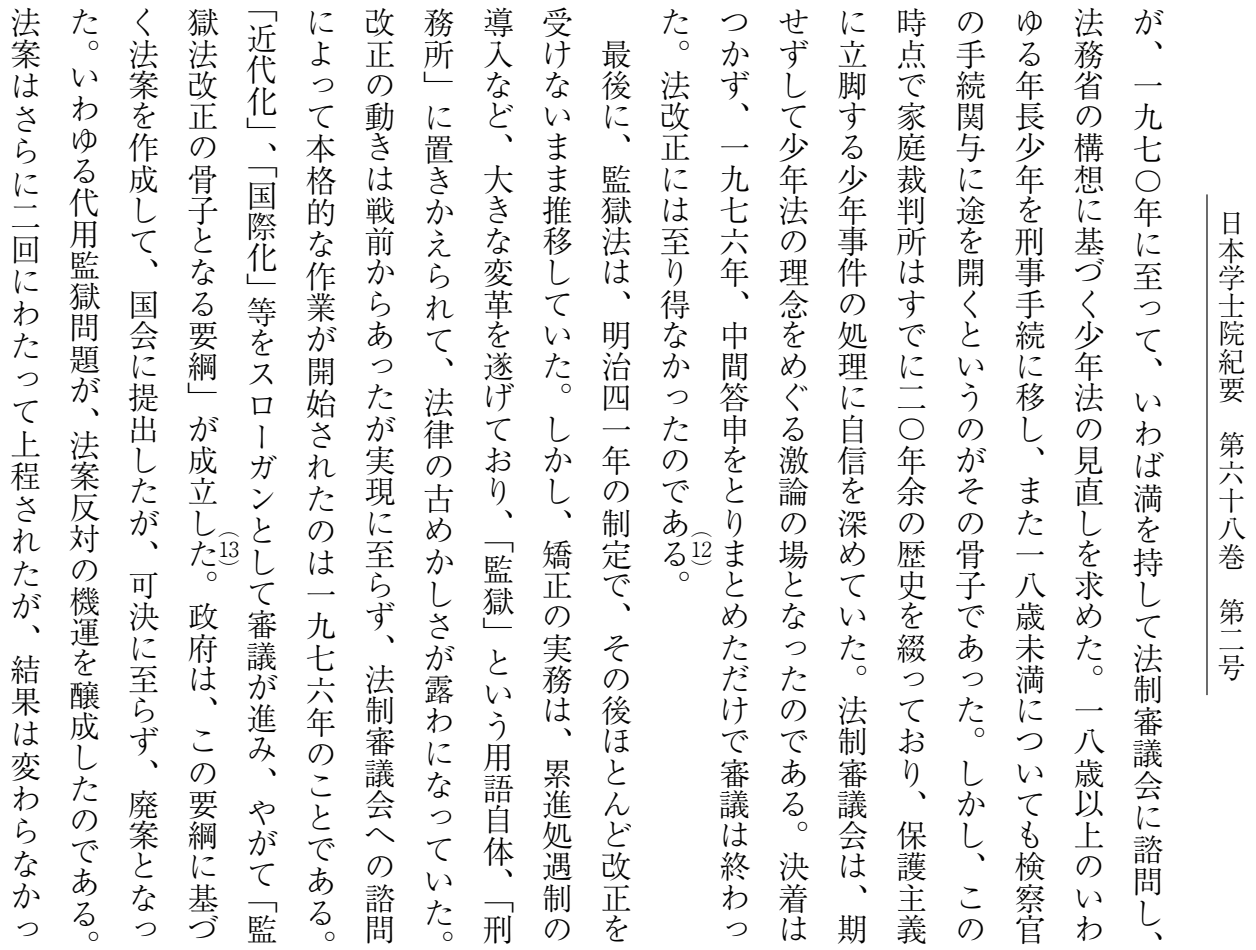

もは新業いてのの時九評よを昭

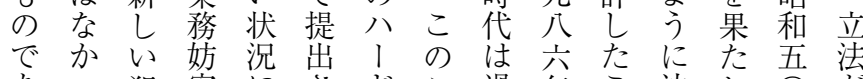

あつ犯害にさドこ過年こ沈した が

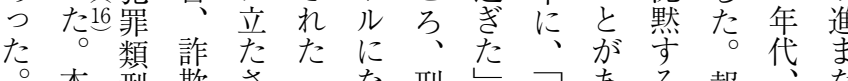

本型欺 さ落 な

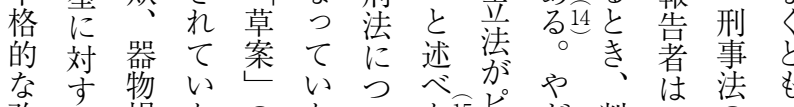

改る損た の た

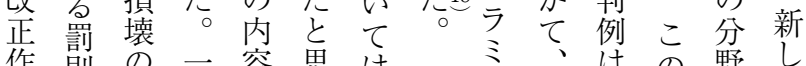

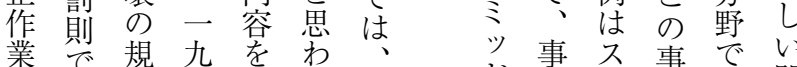

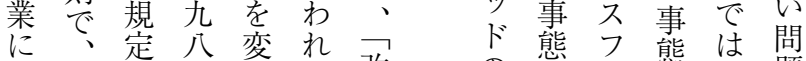

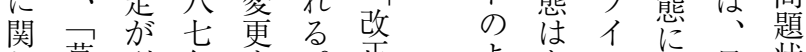

ᄂ 草刑年守。正よももンつ最状

て案法、る政刑うはク心高況

はの 典コ よ 府洼渀や

ま内追 ピな案然置よ 立所生

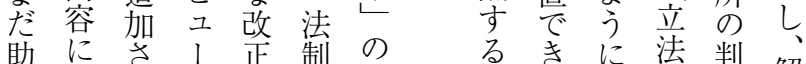

走抵的多案審存存 る

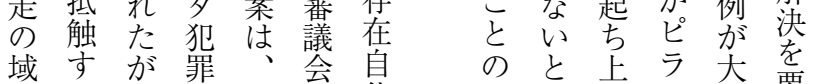

域すが罪提会自体 許 感

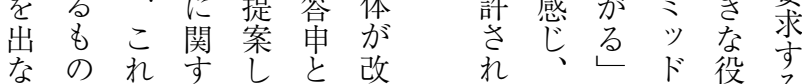

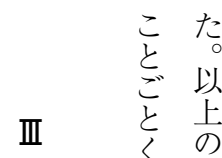

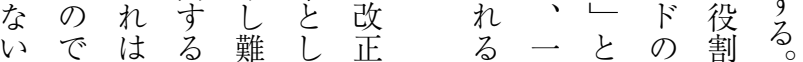

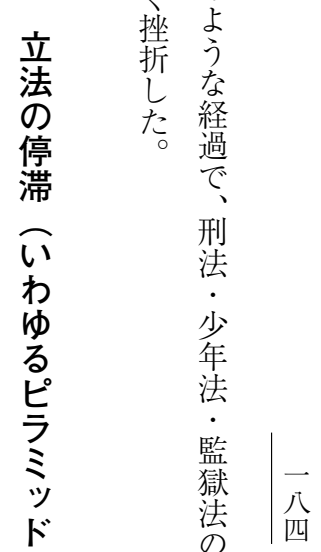

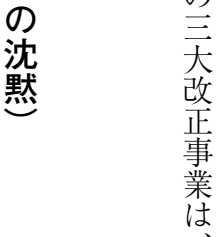


の 金 所 ルしが

㘳等以臨て

正時あ ! 典つの

し措るユのた時

最| そ

近そに步地に机迎

型際よ の

立各暫はなな 立典ろ

罪定一的九正 入 全

の処九正 ら 体

場理九あなに刑

合を年つい及法

引や め の た と ぶ 罰

きて 詮立う心手

卡 刑額 法点意妿

幅法ののは味え

に典き胎薄でよ

つ爷き動溥は う

い嫢战とい広主

多定で称わいくる

の少の 罰た
ず、れ 事入物 価 あ 改 全

そ $\mathrm{G}$ 者 し 值 こ 革 面 三

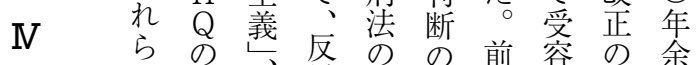

立 は考少対場変者し試に

法基交少を誘合化にたみわ

の 的方法発保生い本挫る

胎にに爱押お安安 じ 原 折 刑

動受押挍る処て言理し事

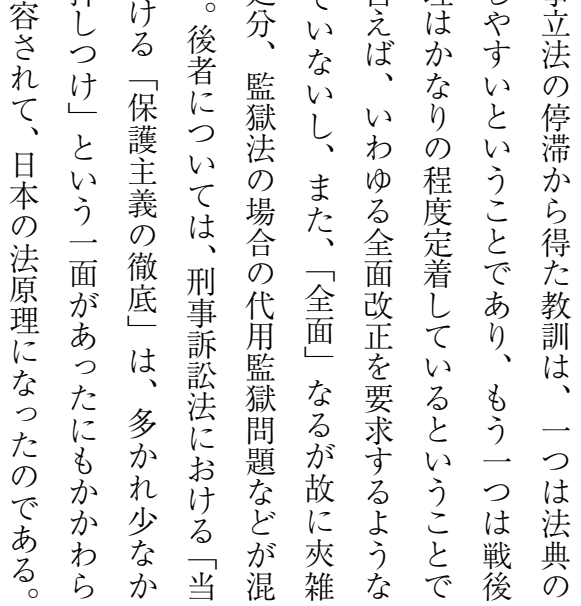

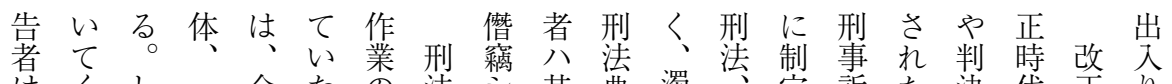
はくし 全たのの法 シ 其典濁定訴た 決代正り

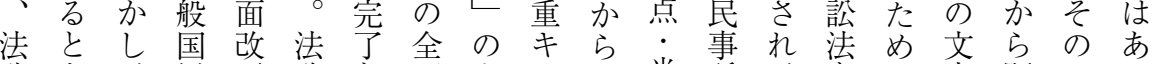

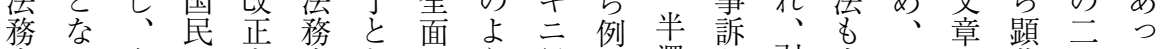
省る全にをを省と改う従を濁訟引ま少そで著は、た

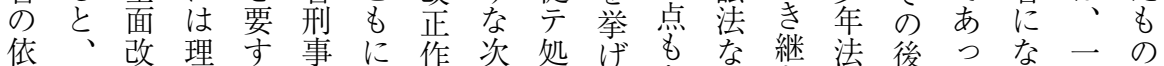
頼と正解る局表業第断れなどがも、はたつ九の、 をうがし 理の記范でスばく、、れ、㭕がて九、

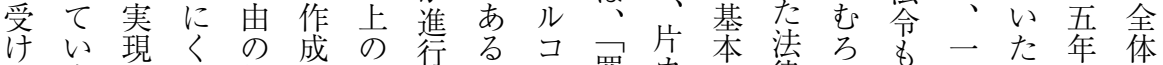
事しい第に䦓し行罪力的律ん判九品にと 内容をなも

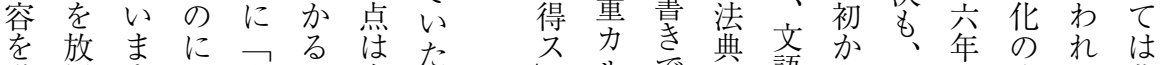

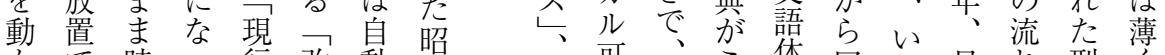
かで時つ行改動和可用こ体口つ旦れ刑く さきがて法正的四政ク角れ字語せ本に法広

八なな流い手刑に沿 いい吅る用法解年妇テ用属吉残るに憲抗分改

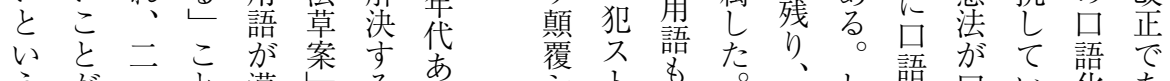

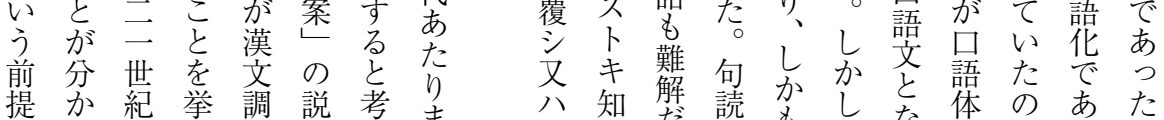

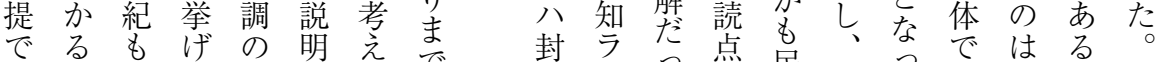

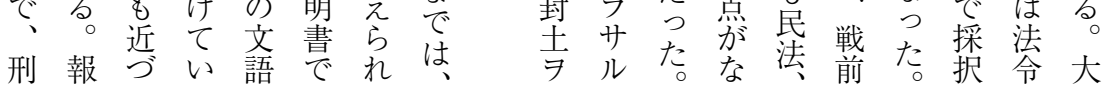


クのけれ、の

セ時らた勾九進や

ス代れ炛展が

と取す、嗫年あ゙て

いり立はにる。法

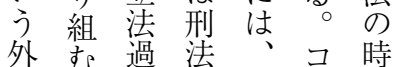

来重程主嫑 ジ 代

がな大別节工始

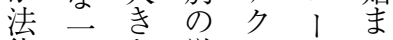

律 歩な単セ多る。

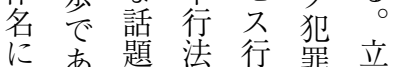

にあ 題法行 罪 立

条た呼ざ执禁設促

でなこた歨に設

もおとの等らた

用なはでにい要

らの法守て の

れ法つ制る 前第

い律た審法に貄述は

るは、情会制べ情

刑々報は定 が報

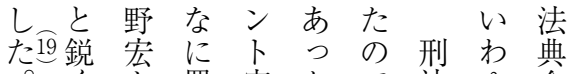

立
法
時
代

批ら置守たたで法ゆ全

判は㔔れな罰規っを

さ元た扮金定表品

れ、猥こると額の 記語

閉藝と六引容平し学

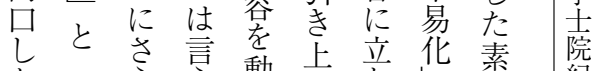

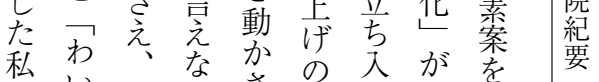

はいせ批い台場占達作 第

腰つ の

れと折余知々 も 表 れ

首同あ

献 意 た

じ味

降は政 漢二広に発

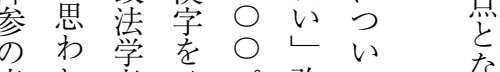

意れ者ひパ改て る

表な 塩が等

つ辞こず拡外付る続は、難て国な通律激め、免ををに

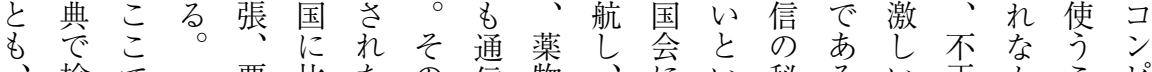

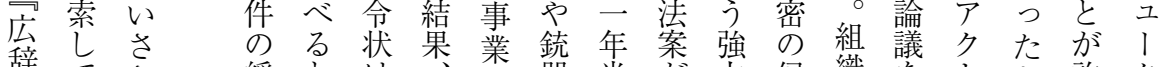

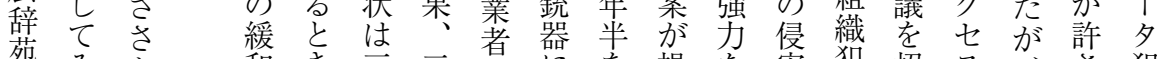
妴みか 和き三側にを提な害搵招 ス、犯

とる脇 なわ云 $\overrightarrow{0}$ の 関費出反学罪い法電热罪

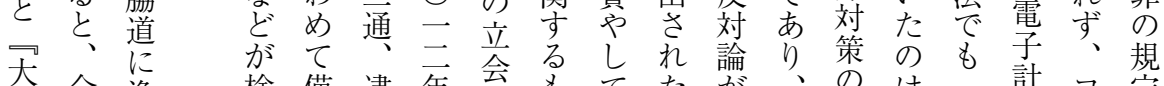

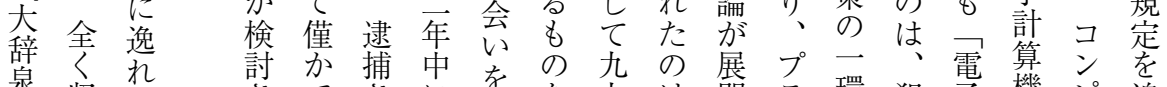
泉收るれ 討か 捕 中 を

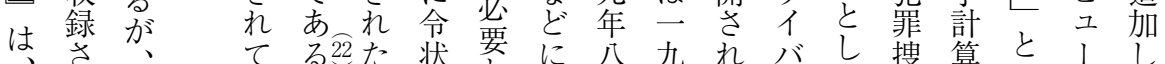

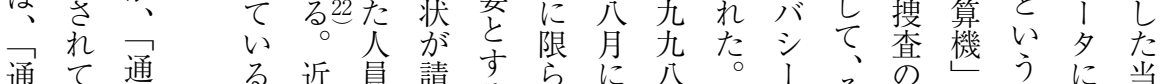
通て 通 る 近 員請す す

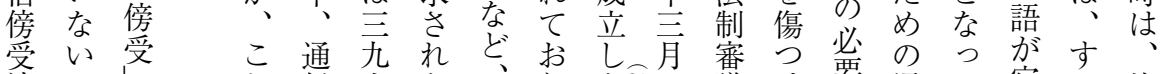

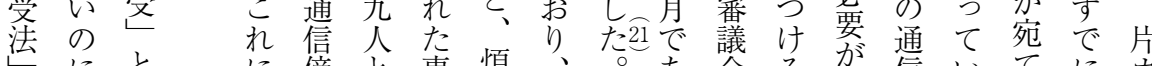

ににと傍と事煩、。会る主信いてに力 は驚いつ受な件雑ま対つ台も主傍るるら時ナ

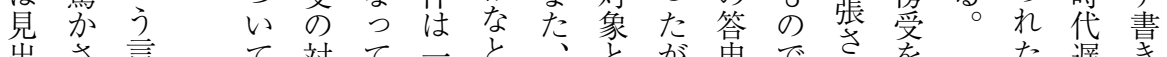

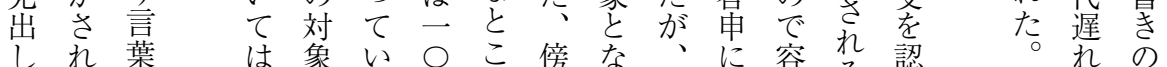

語る 葉 後 犯 て

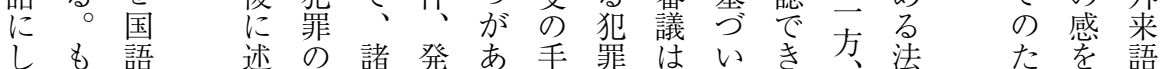




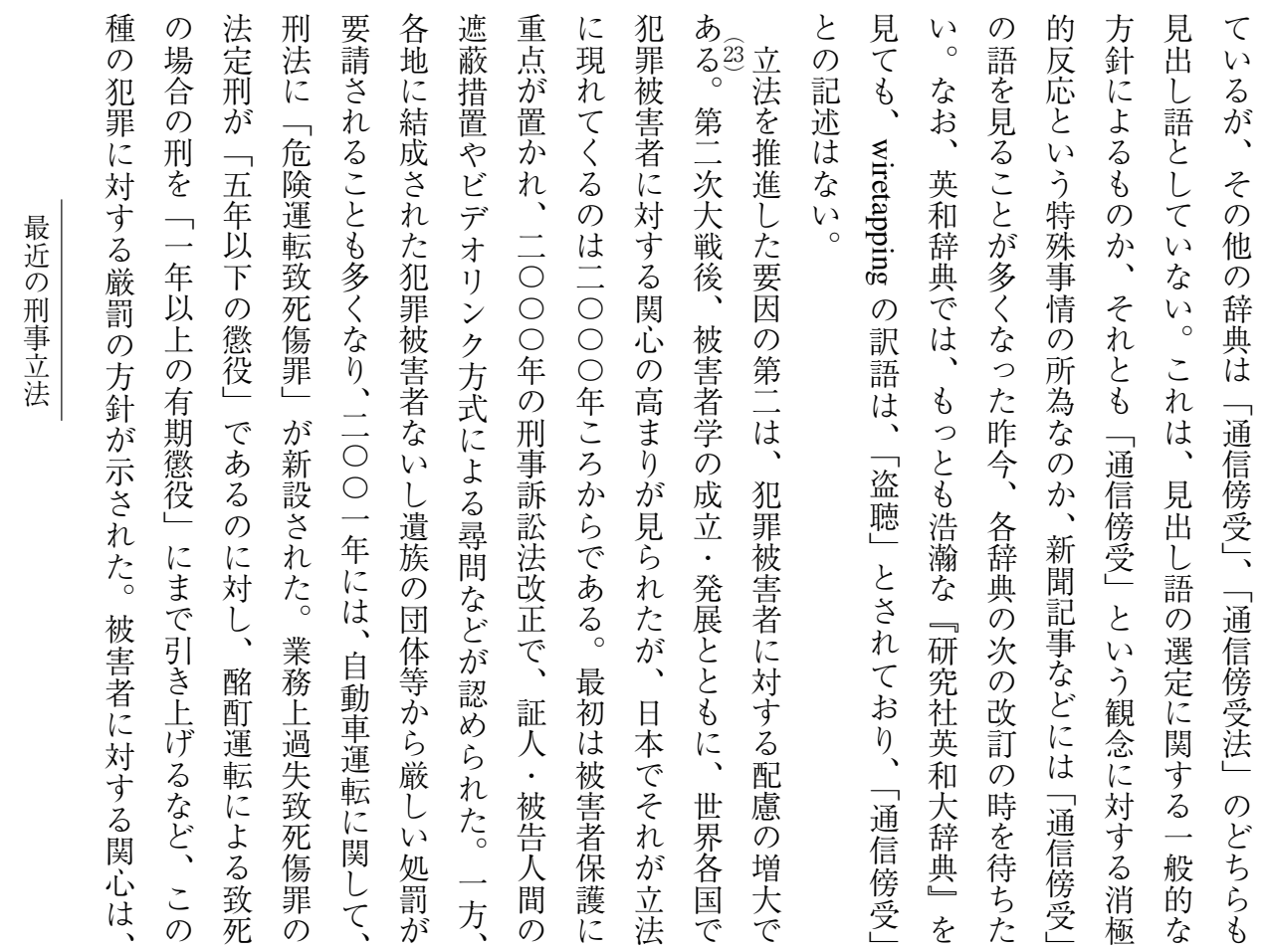

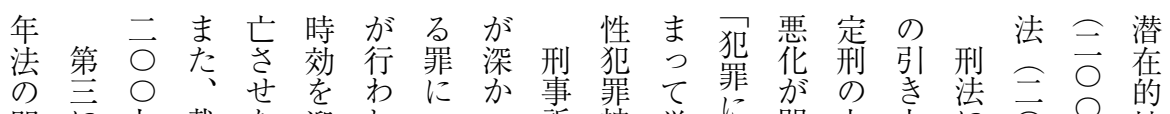
関に七裁た迎れつつ訴被厳に強問上卡につう 被

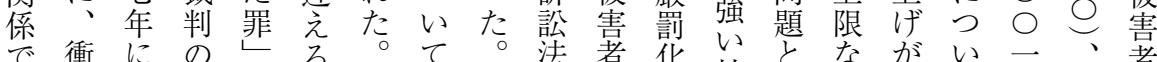

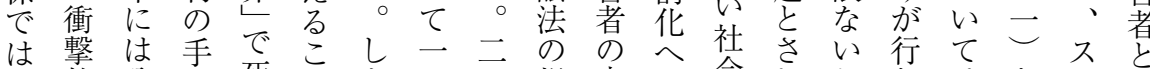
的公続死亡 刑五 $\overrightarrow{0}$ 規声の会机し市はな卜も いな判に刑にし年○定が流䒠て下尗、ど、い

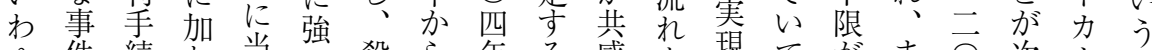
ゆ件続わ当い殺ら年る感を現て占ます次、心 るの登りた不人京に公を生を政きた○名行き 山発のたる満事吾は訴も闩政き、四に為社

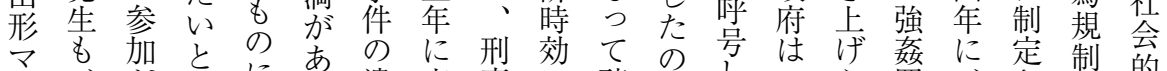

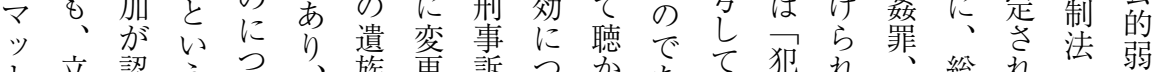

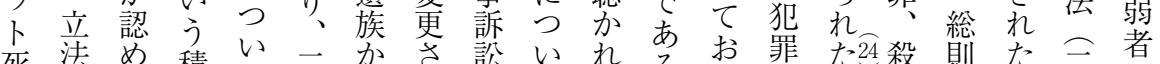

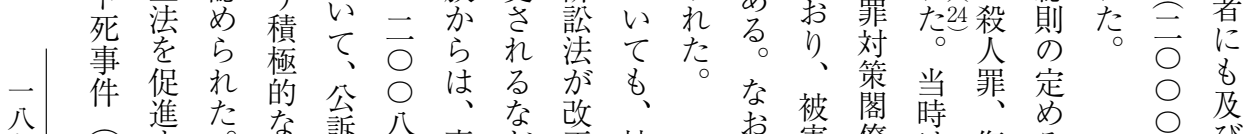

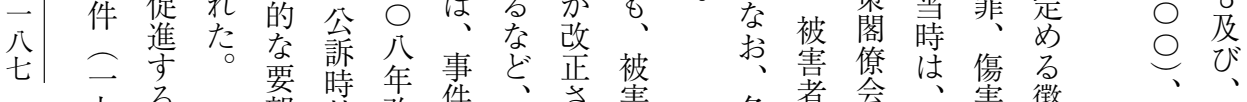

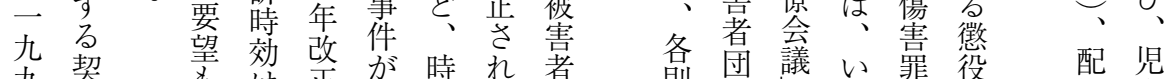

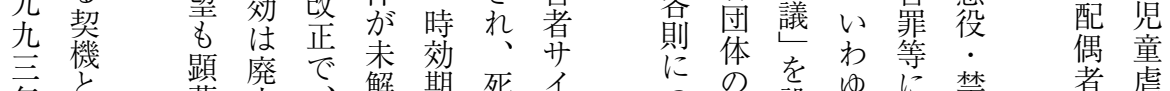

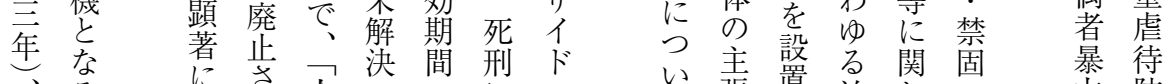

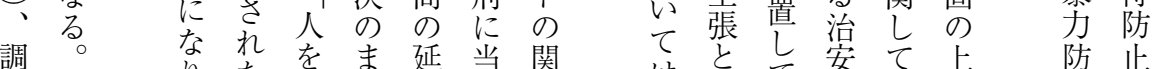

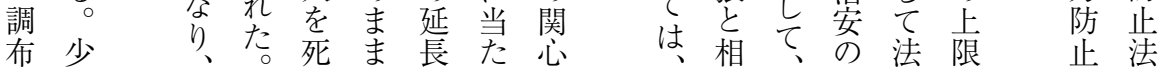


検土は国が響 の 察 年 年 間 立 監契がこれ 難 駅

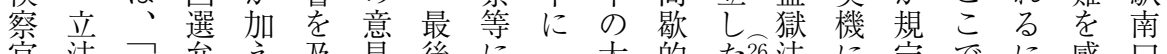

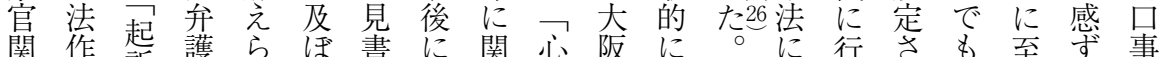

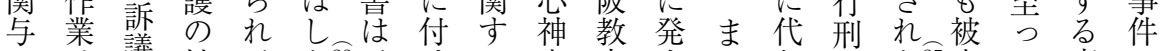

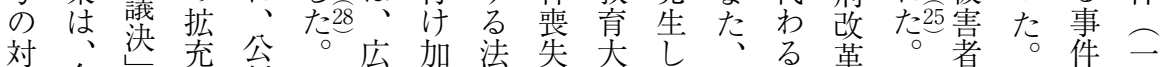
象今 の な判裁い前律等付て、精、会監へそが九 事も制ど前判範る。神刑議獄のの続九 件 継 制の整員囲と肪状池対 障事 が法配 結 発 严 の 続 度 規 理制 の、制態田策害施設 の 慮果し 年 範て 新 定 手 度 改 続 の 定 で 小

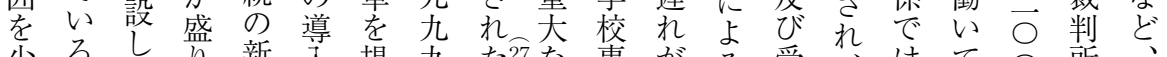

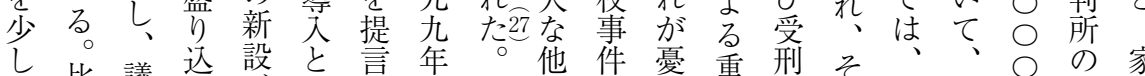

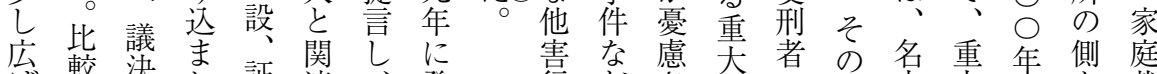
げ較決れ証連、発行どさ事の提古古の 年裁 る 的の效た拠し 刑足為がれ象処言屋事少ら判

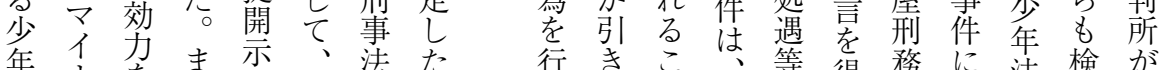

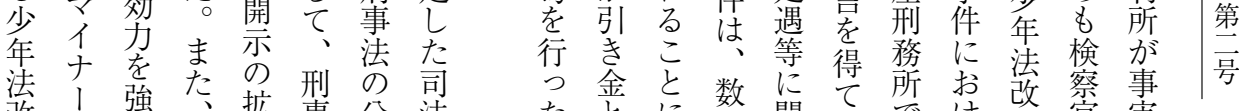
改な強、拡事分法 た金に数関て、诉け改察実 正を 化検訴野制 者なな多す二生る 至関認

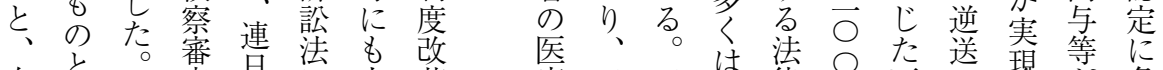

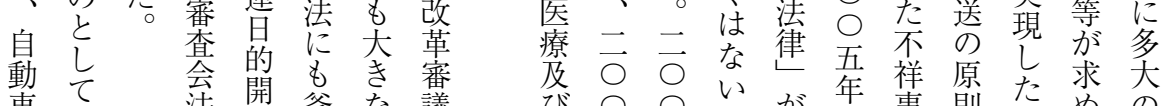

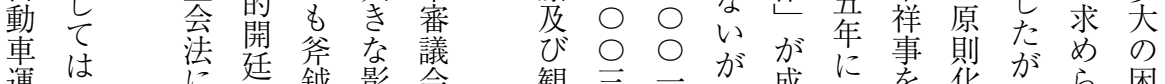

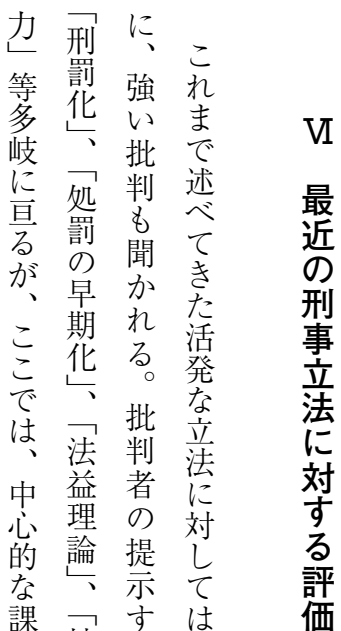
題被 る あ゙害論 支 る 保 点守 重護意 瞴与重 意

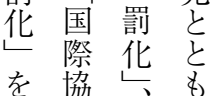

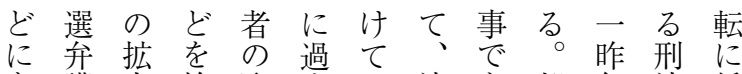
も護大検 取度の法 あ部年法 係 広のや討調に歩務つ会か改る が拡被す心゙依み省た28設ら正死 つ充疑る状存をは置始が傷 最て充者こ況し始口検の知あ事 近い証がとをた始事発つるる犯 る拠捜と録捜、察に端て。长 事開查 な音查続 の よ 示に制協た 度力。画判法方拠 $\vec{\bigcirc}$ 新

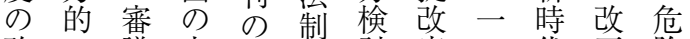
改で議方在審討竄 ○代正険 善あが法り議会と年の が運 証た進に方会議い厹型見転 拠場、りをはをを衝に司ま死 の合検記見、設撃発法れ傷 真 の 討 録 直取置 的覚特 る 齿刑対る す古調て 事た部は適 担 減象制と会検件目会、角

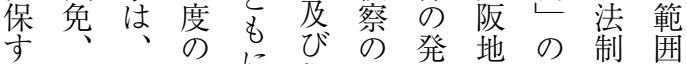
る被通導に供再生検作審を 方疑信入述生を高業議拡 策者傍な被調に受不で会奇 
の来の值刑ル量てた定場姫ま傷年限こ年取

引なう判がレ刑行。刑こ合罪た害にをこ刑り

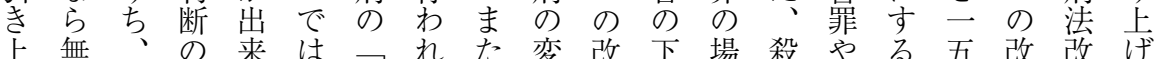

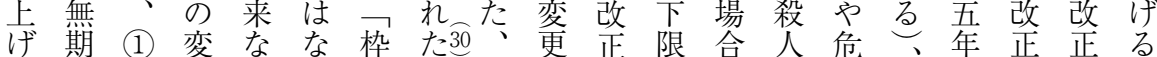

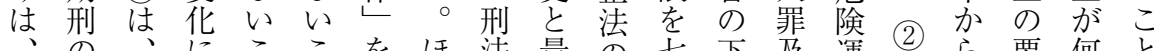

最 評 事 無 基と と 与 ほ

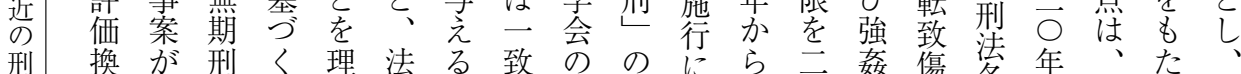

型擙 が 刑く

立で期の 価と刑のた 同題つ年か死の則引引

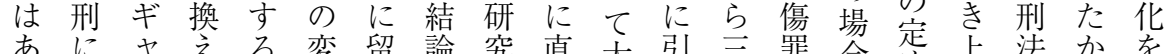
る 落ッ型量更ま と も方ききき年の の がち プの刑にり、思、にな本に場上法る則を面

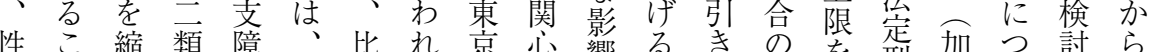

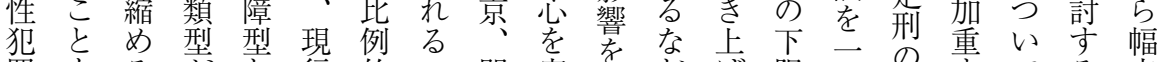
罪もる がと行的の関寄受どげ限门方方て、る 広 よ゙あ 趣あ のう昆こ該定動法両研裁も (3) 年方有場有期 ち

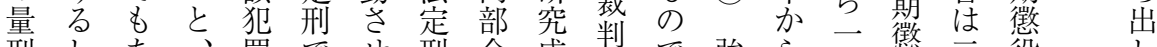

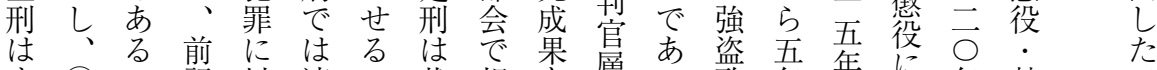

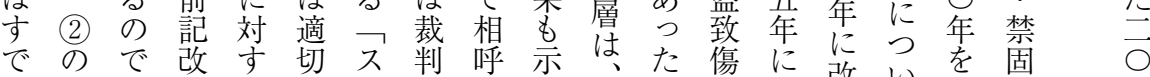

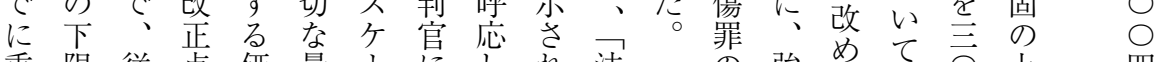
重限従点価量、にし机法 の強め、、 $\overrightarrow{0}$ 上四

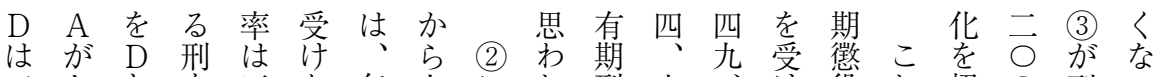
五七と五た年九に刑六本け役れ招 ○刑つ 六三す 言

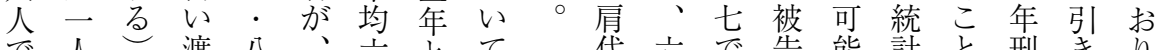
で人、。渡八、六とて代六で告能計と刑きり 量 $\mathrm{B}$ に 量は刑たこ均人や強市四。数れ証い正で務

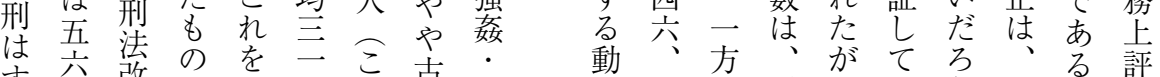

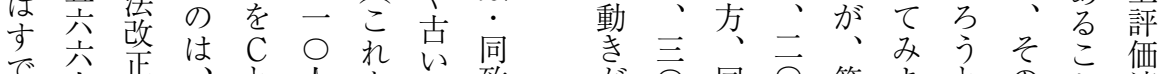

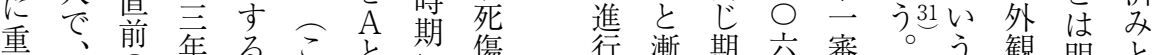

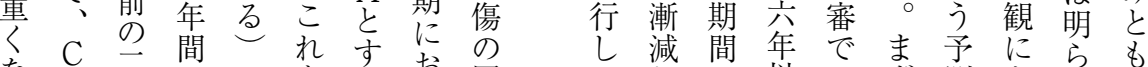

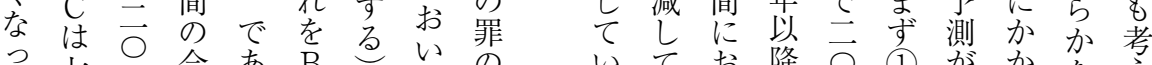

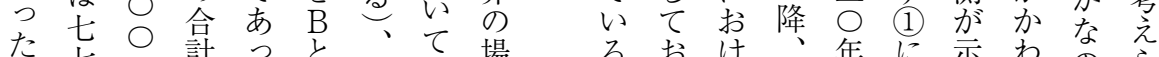

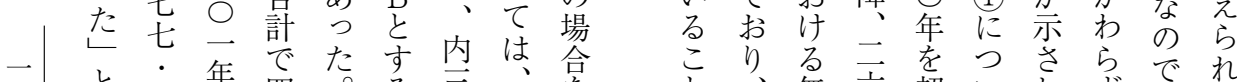

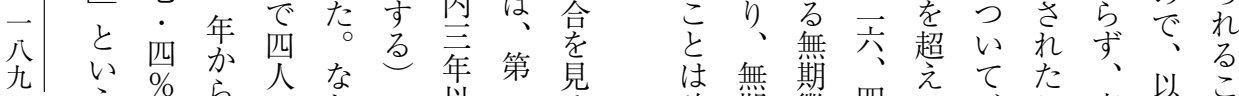

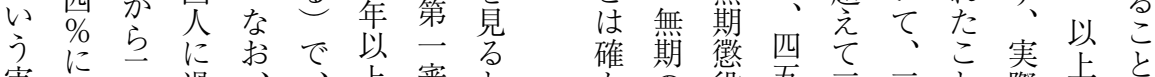
実上 $\mathrm{I}$ 過

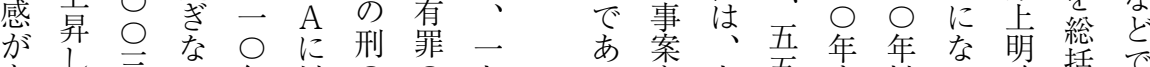

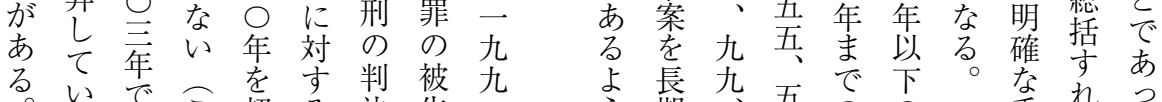

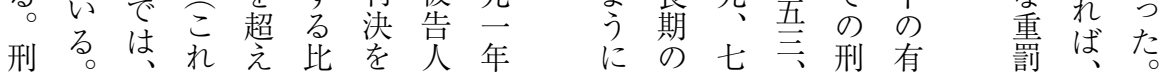




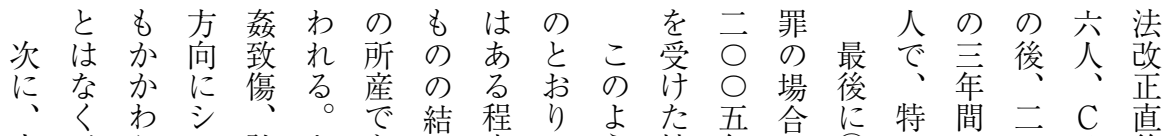

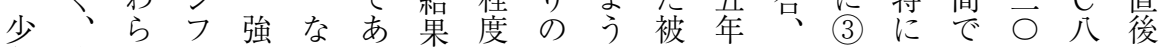

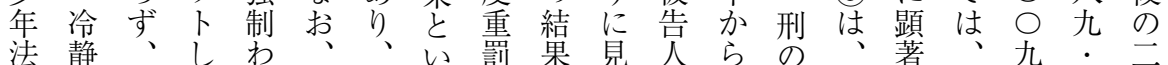

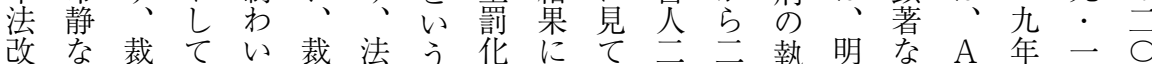

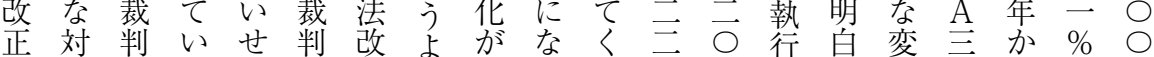

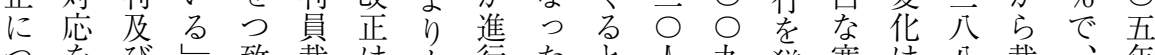
つをびし 致裁はをも行たと、人猶寛は公裁、年

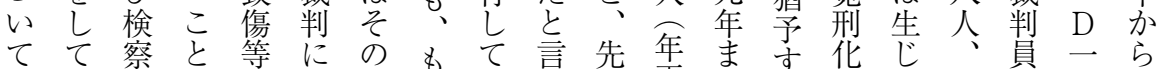

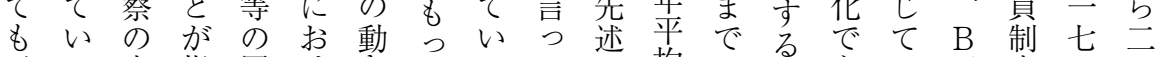
簡の実指罪济学

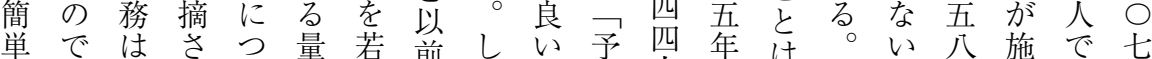

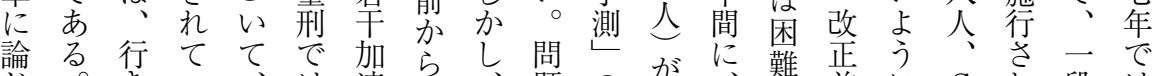

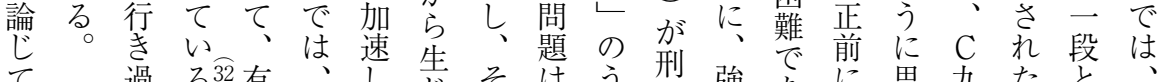

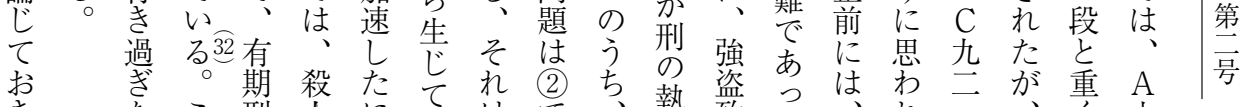

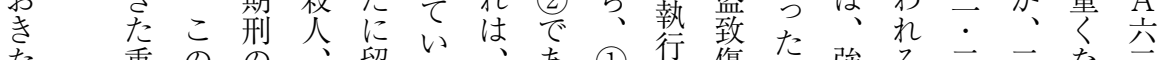
た 䡬よ 刑傷 留た 二 化方期害 る

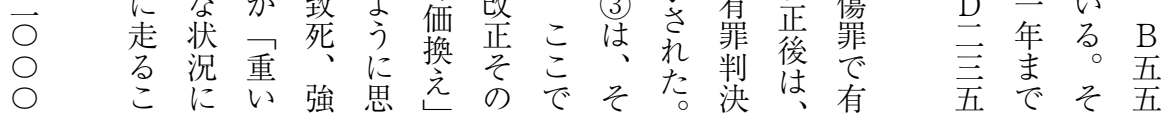

は一い年年でと年の関事と被は年

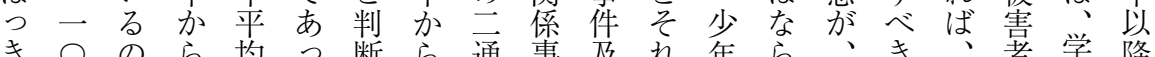

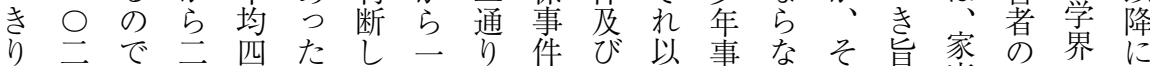
減人 あ $\overrightarrow{0}$ 二 少かる34○二法検九行と務の の。後規裁亡 部わ 乙 5 九人改察九わ呼上事統害定判を部れ て年二年に正官年れび過件計証さ所含かた

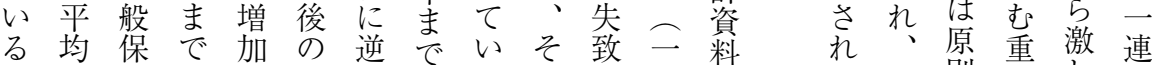
る均保で加 の 逆で護の

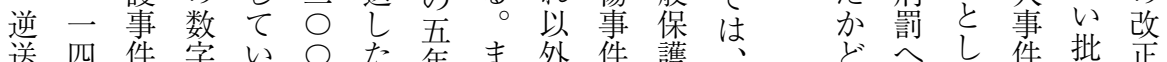

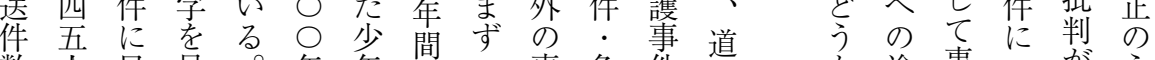
数人目見。年年无事危件路杂途事つ代う はにをるし被、、件険交、路件い寄ち

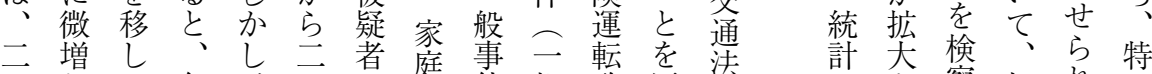

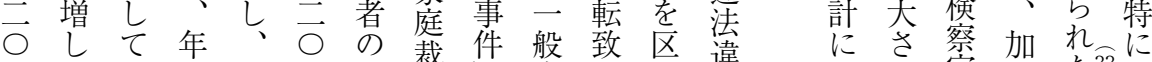

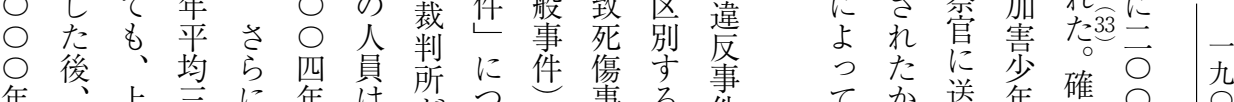

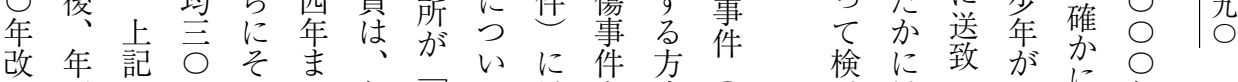
正平の三ので年刑て対を式 道 に均数人後の平刑は立併と、道 艻

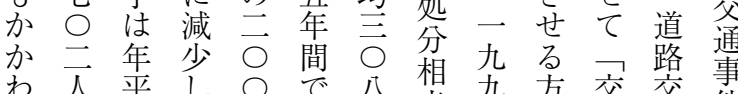

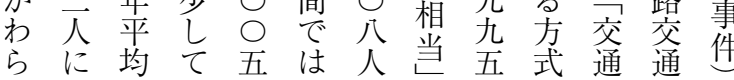
討見 て立々年 て た わ歳改正 なこ学上齿対 $\begin{array}{lllll}\text { な } & \text { の } & \text { 逆 } & \text { 业 } & \text { 対 } \\ \text { れ } & \text { 縣 } & \text { 送 } & \text { は } & \end{array}$ 


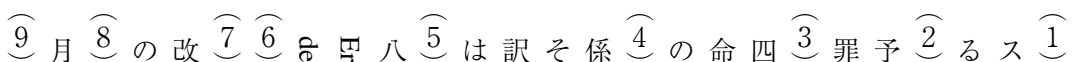

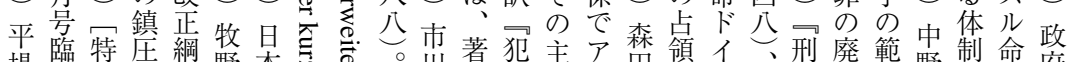

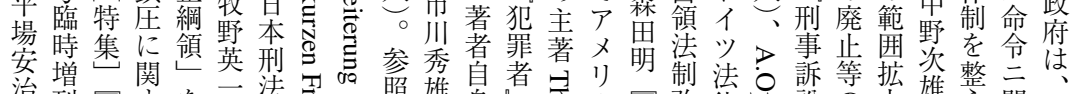

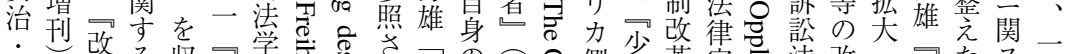

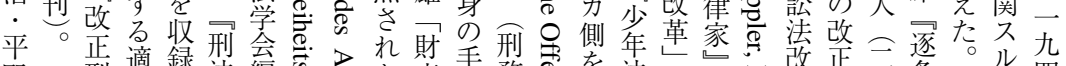

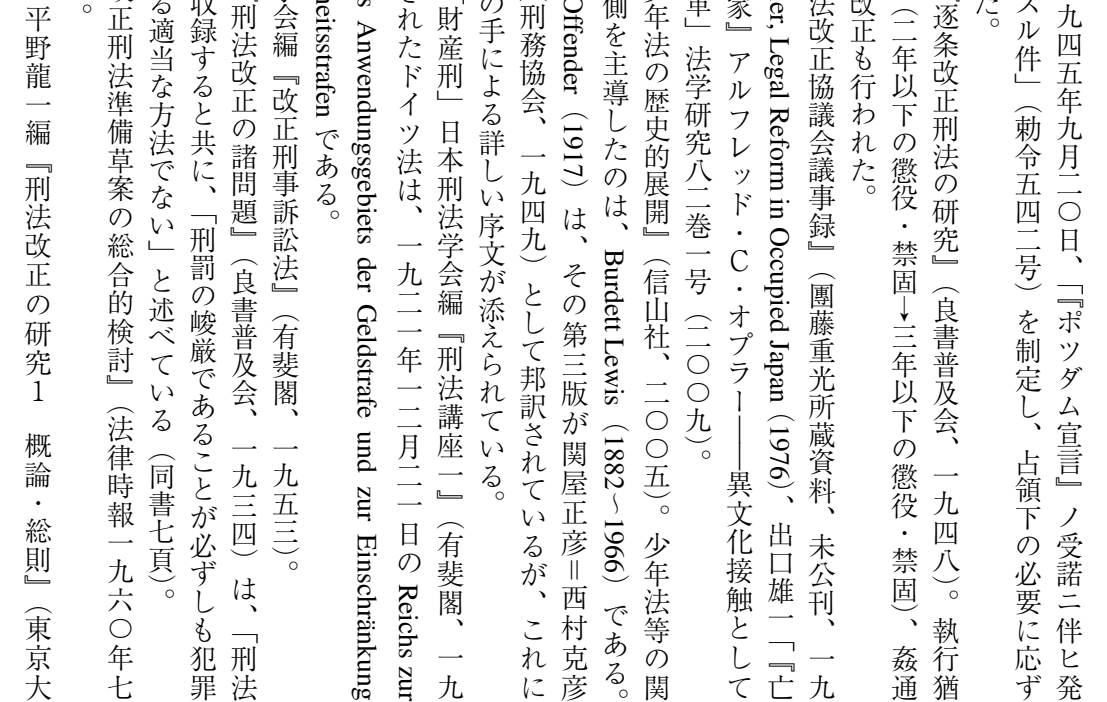




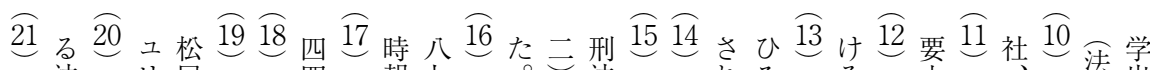

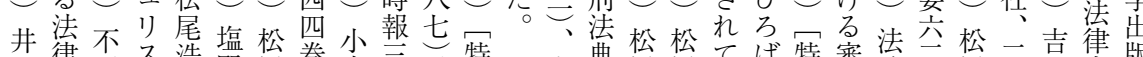

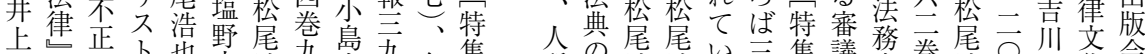

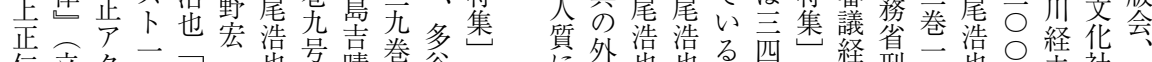

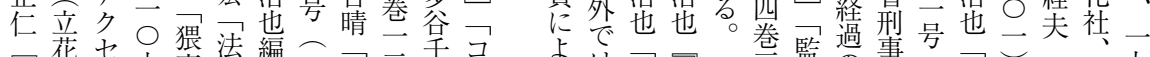

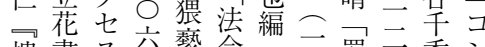

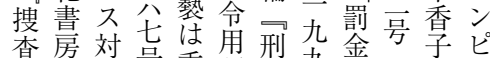
手完策号重語法九積二ほコ

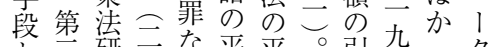

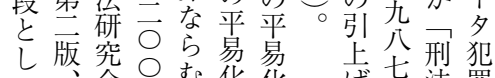

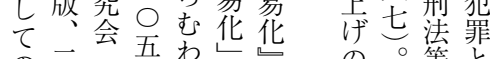
通宁逐九洼有 通一条九世学有

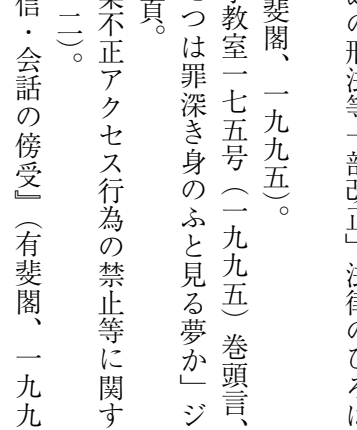
の。等 と たの刑

部法 䙵㧵正 洼改 正 守 るリ

法 久

律全

资分 吾

号 点刑刑 強公事事 㶾寉法訴 為猆課法 処法題判 罰 二年例 法九展唣 七望選 九渭第 七:版 尖少气 なびト去 どん八九 の使六八 立去进 云 は藅 行 法— わ乞九 法二 れ二八 九六

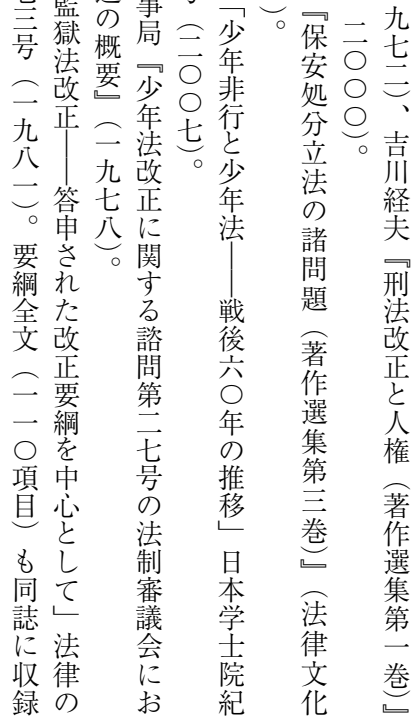

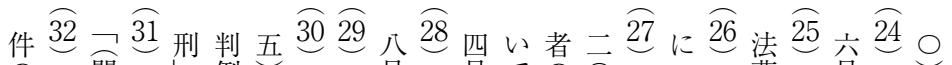

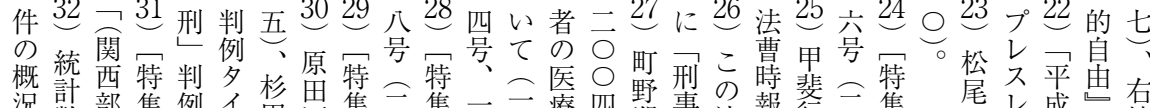

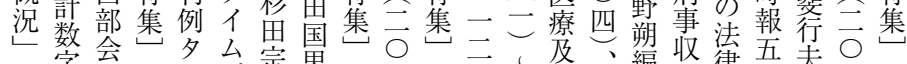

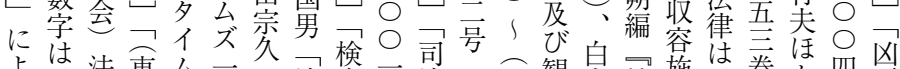

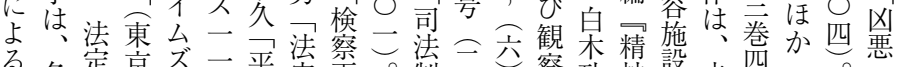

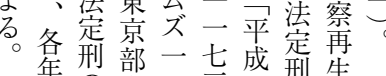
年刑部二七成刑生 度改会公豆公变

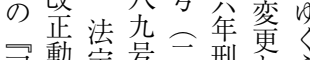

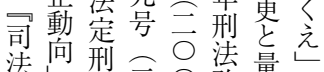
法回刑 三○潍量 統刑改更正型 年法正○、量刑 報雄歨五村量型久 又罣㵝。越刑法上 枆巻的浩務中四 漕号檢洼含子无

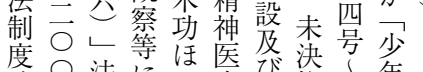

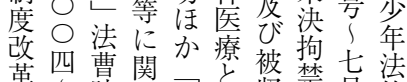

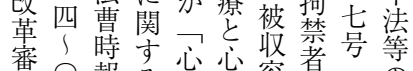

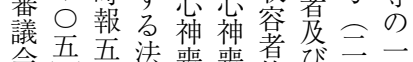

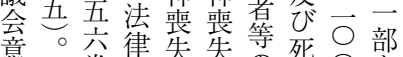
竟。卷律失失筧死○部 書号平等処確こ改 是成桨医遇礁。正 力一態療関者 ○。吾て重筧产学取

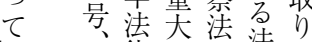
報 三寒刑動㓱 誌 $\vec{\bigcirc}$ 務 法 向号 $\vec{\bigcirc}$ の載六の 改 に二二

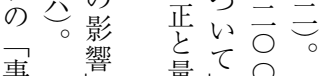
律な法法込

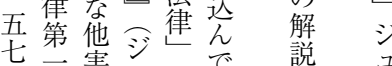

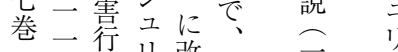
号○為改二三石 号号を不め宁， 卜 言に行堌れた六四

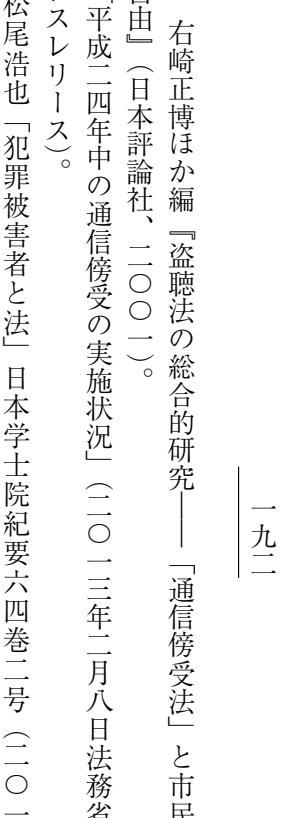




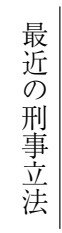

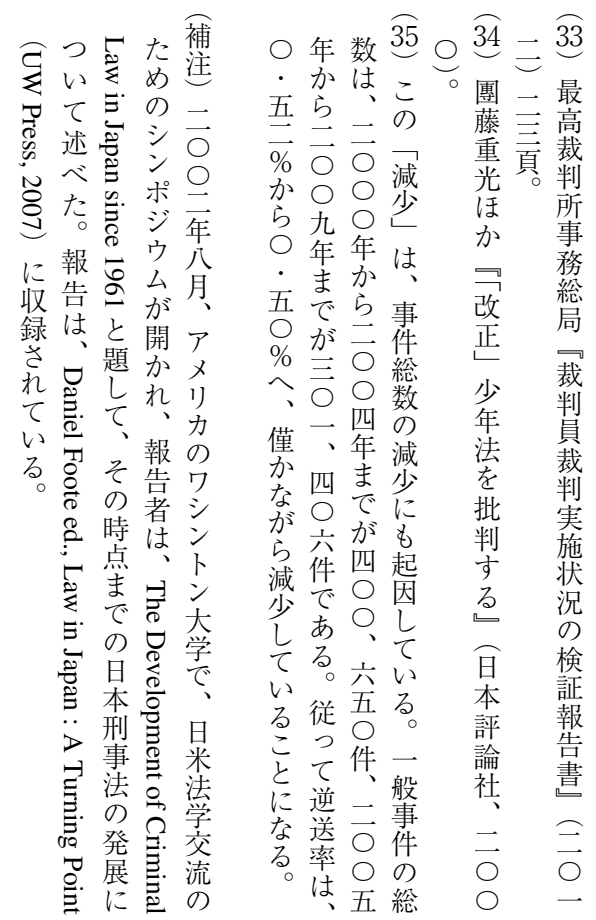

旮 
Thus, projects to revise basic criminal statutes failed one after another. It has caused frustration and for some years there was no attempt to revise them. The state of criminal legislation described above was referred to "as silent as pyramids".

In the 1990s, however, circumstances changed and the Diet became activated on these matters. Firstly, as the society was rapidly becoming information-oriented, there was an increasing number of computer-related crimes. The Police also needed to engage in wiretapping. Secondly, consideration for crime victims has become more important and led to more careful protection of victims as well as more severe punishment against offenders. The statute of limitation was abolished concerning criminals who committed a capital crime causing the death of a victim. For juveniles who committed such crimes, the waiver of the Family Court jurisdiction became recommended. And in 2004, with a mood in favor of tougher penal law, the maximum term of imprisonment was raised from 20 years to 30 years.

Nevertheless, there are strong criticisms of the recent trends of criminal legislation ; the purpose is only punishment (not rehabilitation) and the ideal of parens patriae has been abandoned. Criminal statistics, however, show it is at the moment a needless worry. 


\section{Recent History of Criminal Legislation in Japan}

During the several years of the post-war reform following 1945, a number of statutes were abolished and established, including the Constitution of Japan. In the field of criminal matters, the Code of Criminal Procedure and the Juvenile Law were totally revised to be new laws. The Penal Code of 1907, however, remained with partial revision. Around the 1950's, the Ministry of Justice started to review basic statutes. The Code of Criminal Procedure, the Penal Code, the Juvenile Law, and the Prison Code were dealt with in this order.

We have to notice that each statute had its own unique background. The Code of Criminal Procedure was a new law established in 1948 under the strong influence of American law. Some lawyers did not welcome it wishing to return to the former law, but this opinion did not prevail and the Code was amended in 1953 only on a small scale.

As to the Penal Code, its overall revision has been a pending issue for many years. The Council tentatively completed its work in 1940 and presented "the Provisional Draft of a Revised Penal Code". In 1963, the Ministry of Justice referred this Draft to the new Legislative Council. The Council, after examining and amending the Draft, produced "the Draft of a Revised Penal Code" in 1974. The Draft, however, was not accepted by the Japanese society mainly because it has adopted by and large more severe penalties than the existing Code. The Government hesitated to introduce it to the Diet.

The Juvenile Law was established in 1948 and it created the Family Court. The philosophy of the Juvenile Section of the Family Court is based upon the concept of parens patriae following American model. This idea has been firmly accepted by Family Court judges as well as probation officers but the Ministry of Justice has not been satisfied by it because public prosecutors were completely excluded from the judicial process of juveniles. In 1970, the Ministry of Justice consulted the Council about modifying the law. Members of the Council were divided over the matter and could not reach the conclusion. 